\title{
Loyaliteitsregelingen; lessen uit Frankrijk en Delaware
}

\author{
Mr. K.J. Bakker*
}

\begin{abstract}
Een aantal Nederlandse beursvennootschappen heeft een loyaliteitsregeling, bedoeld om aandeelhouders te prikkelen op lange termijn betrokken te blijven bij de vennootschap. In deze bijdrage onderzoekt de auteur welke lessen daarvoor kunnen worden ontleend aan de ervaringen met loyaliteitsregelingen in Frankrijk en Delaware.
\end{abstract}

\section{Inleiding}

Nederlands aandeelhouderschap bevindt zich in een interessante fase. Aandeelhouders(bevoegdheden) zijn, zeker in het afgelopen decennium, steeds verder aan banden gelegd, terwijl de bestuursautonomie in toenemende mate in beton is gegoten. Deze ontwikkeling is ingegeven door wantrouwen jegens het kortetermijndenken van veel beleggers.

Tegelijkertijd verwacht de wetgever wel meer verantwoordelijkheid van aandeelhouders. Dit is (mede) de strekking van de Richtlijn langetermijnbetrokkenheid aandeelhouders. ${ }^{1}$ Deze richtlijn bevat verschillende verplichtingen voor onder andere institutionele beleggers en vermogensbeheerders. Het is een fraai plan: juist die partijen hebben de slagkracht om verantwoord beleid af te dwingen. ${ }^{2}$ Het is echter ook een incompleet plan: het bevat geen prikkels voor dergelijke partijen om ook daadwerkelijk langetermijnwaardecreatie na te streven (nog los van de vraag of de aandeelhouder daarvoor geëquipeerd is). ${ }^{3}$ Een eerdere (concept)versie van de richtlijn bevatte wel een dergelijke prikkel: een bepaling die loyaliteitsregelingen mogelijk moest maken, oftewel regelingen die aandeelhouders belonen voor het langer en voortdurend aanhouden van hun aan-

* Mr. K.J. Bakker is promovendus en docent (notarieel) ondernemingsrecht bij het Van der Heijden Instituut, dat deel uitmaakt van het OO\&R van de Radboud Universiteit Nijmegen.

1. Richtlijn (EU) $2017 / 828$ van het Europees Parlement en de Raad van 17 mei 2017 tot wijziging van Richtlijn 2007/36/EG wat het bevorderen van de langetermijnbetrokkenheid van aandeelhouders betreft (hierna: Richtlijn langetermijnbetrokkenheid aandeelhouders 2017).

2. M.C. Schouten, The Decoupling of Voting and Economic Ownership (IVOR nr. 88), Deventer: Kluwer 2012, p. 209-214 toonde dit aan voor mutual funds (de Amerikaanse tegenhanger van een beleggingsinstelling).

3. B. Elion, De herziene Richtlijn Aandeelhoudersrechten in Nederland, MvO 2018, afl. 1-2, par. 5.1 drukte dit vermoeden eerder ook al uit. delen. Deze bepaling heeft om onduidelijke redenen de eindstreep niet gehaald. ${ }^{4}$

Toch zouden loyaliteitsregelingen langetermijnbetrokkenheid kunnen faciliteren. Niets weerhoudt Nederland ervan invoering van een wettelijke loyaliteitsregeling alsnog te (her)overwegen. ${ }^{5}$ In dit artikel verken ik daarom of een dergelijke regeling wenselijk is, en zo ja, onder welke voorwaarden. Ik trek daarvoor lessen uit de Franse en Amerikaanse ervaringen met loyaliteitsregelingen. In Frankrijk maakt de wet loyaliteitsregelingen al langer mogelijk, waardoor de Franse ervaring waardevol is. Amerikaans (Delawareaans) ondernemingsrecht kent een met Nederlands ondernemingsrecht vergelijkbare situatie; er is geen wettelijke mogelijkheid van loyaliteitsregelingen, maar verschillende vennootschappen hebben zelf loyaliteitsregelingen geconstrueerd. Bovendien hebben de Verenigde Staten wel ervaring met een verwante rechtsfiguur, namelijk dual class shares. ${ }^{6}$ Dit houdt in dat er twee aandelensoorten zijn, waarvan één met veel stemrecht en één met weinig of geen stemrecht.

Ik schets in paragraaf 2 de Nederlandse stand van zaken omtrent de positie en verantwoordelijkheid van aandeelhouders in beursvennootschappen en het probleem dat de richtlijn wil oplossen. In paragraaf 3.1, 3.2 en 3.3 behandel ik respectievelijk de Nederlandse, Franse en Amerikaanse loyaliteitsregelingen. Ik beschrijf in paragraaf 4.1 de argumenten die in de verschillende landen zijn aangevoerd voor en tegen loyaliteitsregelingen. In paragraaf 4.2 verken ik welke lessen

4. Art. 3 sexies bis (art. 3d a in de Engelse versie), voorgesteld bij amendement in het Europees Parlement. Zie Draft report Sergio Gaetano Cofferati, 5 februari 2015, amendementen 42 en 211, te vinden via www. europarl.europa.eu/sides/getDoc.do?pubRef=-\%2F\%2FEP\%2F \%2FNONSGML\%2BCOMPARL\%2BPE-544.471\%2B01\%2BDOC $\% 2 \mathrm{BPDF} \% 2 \mathrm{BV} 0 \% 2 \mathrm{~F} \% 2 \mathrm{FEN}$ en www.europarl.europa.eu/sides/ getDoc.do?pubRef=-//EP//NONSGML+COMPARL+PE-549. $129+01+\mathrm{DOC}+\mathrm{PDF}+\mathrm{V0} / / \mathrm{EN} \&$ language $=\mathrm{EN}$.

5. Hier is door het ministerie van Veiligheid en Justitie al eens over gefilosofeerd. Na onderzoek door de minister was de conclusie toen dat nadere regeling niet nodig was. Zie Kamerstukken II 2010/11, 31980, 48 en eerder Kamerstukken II 2005/06, 30419, 3, p. 10-11 en Kamerstukken II 2005/06, 30419, 8, p. 15.

6. Ook wel high/low voting stock genaamd, waarover verder A.A Bootsma \& T.A. Keijzer, 'Snap Inc.', OR 2017/68, M.P. Buirma, High/Low Voting Stock - Een nieuwe trend?, TOP 2016/99 en A.A. Bootsma, Loyaliteitsdividend, bijzondere stemrechtaandelen en de positie van minderheidsaandeelhouders, MvO 2016, afl. 7, p. 151-160. 
Nederland kan leren van de Franse en Amerikaanse ervaringen, gevolgd door een conclusie (par. 5).

\section{Probleemschets: veranderend aandeelhouderschap en de nieuwe aandeelhoudersrichtlijn}

De EU heeft in 2017 de Richtlijn langetermijnbetrokkenheid aandeelhouders in het leven geroepen. Deze creëert onder andere een aantal randvoorwaarden voor aandeelhouders om zich actiever op te stellen en om tegengewicht te bieden aan kortetermijnhandelen. ${ }^{7}$ Concreet legt zij verplichtingen op aan onder andere institutionele beleggers en vermogensbeheerders, hoofdzakelijk betreffende transparantie, goede governance en aandeelhoudersverantwoordelijkheid. ${ }^{8}$ Van dit soort aandeelhouders verwacht de wetgever - ook de nationale - in toenemende mate een maatschappelijk verantwoord beleid.

Tegelijkertijd hebben juist deze beleggers een achterban waaraan zij op hun beurt verantwoording verschuldigd zijn. Het risico bestaat daarom dat de richtlijn niet bijzonder veel effect zal sorteren. De richtlijn bevat namelijk geen concrete prikkels (of bevoegdheden) voor deze beleggers om zich niet alleen op hun eigen (financiële) belang te richten, maar daadwerkelijk actief en 'langetermijnbetrokken' te worden. Zonder die prikkels of bevoegdheden lijkt de kans groot dat nadere verplichtingen voor institutionele beleggers omtrent maatschappelijk verantwoord stemgedrag hun doel zullen missen. ${ }^{9}$ Aandeelhouders mogen en zullen zich bij uitoefening van hun stem-

7. Zie over short-termism D.J. Berger e.a., Tenure voting and the U.S public company, The Business Lawyer 2017, p. 298-303; F.G.K. Overkleeft, De positie van aandeelhouders in beursvennootschappen (IVOR nr. 104), Deventer: Wolters Kluwer 2017, hoofdstuk 5 en 6; J.M. de Jongh, Tussen societas en universitas (IVOR nr. 94), Deventer: Kluwer 2014, hoofdstuk 9; P. Bolton \& F. Samama, L-shares: Rewarding longterm investors, ECGI - Finance Working Paper No. 342/2013, http:// ssrn.com/abstract $=2188661$, p. 3-9; L.L. Dallas, Short-termism, the financial crisis, and corporate governance, Journal of Corporation Law 2011, p. 264-363.

8. Zie ov. 3 preambule Richtlijn langetermijnbetrokkenheid aandeelhouders. Vgl. ook C. Clottens, Proportionaliteit van stemrecht en risico in kapitaalvennootschappen, 2011, https://core.ac.uk/download/pdf/ 34506624.pdf, nr. 425. Ik verwijs voor de definities naar het nieuwe art. 2 sub d, e, f en g en noem ter illustratie twee verplichtingen voor institutionele beleggers: een comply or explain-verplichting om een 'betrokkenheidsbeleid' te ontwikkelen (art. 3 octies) en een transparantieverplichting omtrent de afstemming tussen beleggingsbeleid en de looptijd van verplichtingen (art. 3 nonies).

9. Zo constateerde al eerder Elion 2018, par. 5.1, waarnaar ik verder verwijs. Bovendien legt de richtlijn alle verantwoordelijkheid bij de aandeelhouders en geen bij de bestuurders van de portfolio-ondernemingen. recht primair naar hun eigen belang richten, ${ }^{10}$ binnen de grenzen van de redelijkheid en billijkheid en met enige inachtneming van het vennootschappelijk belang. ${ }^{11}$ Naast de over het algemeen zwakke positie van de aandeelhouder(svergadering), ${ }^{12}$ behartigen institutionele beleggers en vermogensbeheerders immers de (financiële) belangen van een achterban. Hoewel niet is uitgesloten dat die achterban aan bijvoorbeeld vergroening van de economie hecht, is financieel gewin het primaire doel; de beleggers hebben veelal geen uitdrukkelijk 'duurzaamheidsmandaat'. Schouten wijst er bovendien op dat institutionele beleggers (kortweg) alleen grondig eigen onderzoek doen naar agendapunten als ze relatief impactful zijn voor de investering. ${ }^{13}$ Sterker: institutionele beleggers zijn evengoed kortetermijnbeleggers als dat in het belang van hun achterban is. $^{14}$

\section{Rechtsvergelijking}

\subsection{Nederland}

Statutaire loyaliteitsregelingen kunnen naar Nederlands recht grofweg op twee manieren vorm krijgen: door de loyaliteitsrechten direct toe te kennen aan de aandeelhouders, in die hoedanigheid (de 'aandeelhouderschapsroute'), of door soortaandelen te creëren en daaraan de rechten te verbinden (de

10. Zie A.M. Brenninkmeijer, Stemovereenkomsten van aandeelhouders (VDHI nr. 8), Deventer: Kluwer 1973, nr. 32 en 101-103; P. van Schilfgaarde, De redelijkheid en billijkheid in het ondernemingsrecht (IVOR nr. 100), Deventer: Wolters Kluwer 2016, p. 224; Slagter/ Assink, Compendium 2013, p. 841-842; Asser/Van Solinge \& Nieuwe Weme 2-II* 2009/383; W.J.M. van Veen, Vennootschapsrechtelijke doorwerking, bestuursautonomie en bestuurstaak bij joint ventures na 'Cancun', OR 2015/88, par. 5; W.J.M. van Veen, Boek 2 BW, statuten en aandeelhoudersovereenkomsten - stand van zaken en blik vooruit (ZIFO nr. 2), Deventer: Kluwer 2011, par. 3; Van der Heijden/Dortmond, Handboek voor de Naamloze en de Besloten Vennootschap, Deventer: Kluwer 2013, nr. 217.1.

11. Aldus o.a. HR 4 april 2014, NJ 2014/286 (Cancun), r.o. 4.2.1 en 4.7.1 Hof Amsterdam (OK) 28 december 2005, JOR 2006/66 (Wielens/ Gekas \& Boot), r.o. 3.2; Hof Amsterdam (OK) 20 mei 1999, NJ 2000/199 (Cromwilld/Versatel), r.o. 3.6; HR 30 oktober 1964, NJ $1964 / 107$ (Mante). Zie voor literatuur o.a. M. Olaerts, Is de aandeelhouder gebonden aan het belang van de vennootschap? OR 2017/113, o.a. p. 633-634 en 642; M. van Olffen, Toezicht in overnamesituaties, in: G. van Solinge (red.), Toezicht (VDHI nr. 151), Deventer: Wolters Kluwer 2018, p. 143; B. Kemp, Aandeelhoudersverantwoordelijkheid; de positie en rol van de aandeelhouder en aandeelhoudersvergadering (VDHI nr. 129), Deventer: Wolters Kluwer 2015, hoofdstuk 5, 6 en 10; De Jongh 2014, p. 217; Van Veen 2015, par. 5, p. 442-443 en 449 en Van Veen 2011, p. 24, die er terecht op wijst dat deze begrenzing al lag besloten in HR 30 juni 1944, NJ 1944/465 (Wennex).

12. Ik ga hier niet nader op in; zie verder H.M. Vletter-van Dort, De aandeelhouder als hoeksteen van de beursvennootschap?, OR 2018/45 en S.F. de Beurs, Loyaliteitsdividend bij beursvennootschappen; gerechtvaardigd?, O\&F 2011/2, p. 13-14.

13. Schouten 2012, p. 160. Zie ook J.M. de Jongh, Reactie: loyaal aan duurzame waardecreatie, OR 2010/152, bij voetnoot 10 en J.M. de Jongh, Het loyaliteitsstemrecht, OR 2009/105, nr. 20.

14. L. Strine, One fundamental corporate governance question we face. Can corporations be managed for the long term unless their powerful electorates also act and think long term?, Journal of Business Law 2010, afl. 1, p. 10 en 32; I. Anabtawi \& L.A. Stout, Fiduciary duties for activist shareholders, Stanford Law Review 2008, par. 38. 


\section{Maandblad \\ Ondernemingsrecht}

'soortaandelenroute'). ${ }^{15} \mathrm{Bij}$ de aandeelhouderschapsroute is de loyaliteitsbonus in zekere zin een persoonlijk recht, verbonden aan de persoon van de aandeelhouder, niet aan een goed (het aandeel). De soortaandelenroute kan twee vormen aannemen. Allereerst kunnen speciale loyaliteitsaandelen naar rato van het geregistreerde belang worden toegekend aan de kwalificerende aandeelhouder. De vennootschap kan de loyaliteitsaandelen nieuw uitgeven, of al uitgegeven en gehouden aandelen toekennen. De vereiste kapitaalstorting op die aandelen kan ten laste van de agio- of een daartoe gecreëerde statutaire reserve gebeuren. ${ }^{16}$ Een tweede mogelijkheid is een conversieregeling: aandeelhouders die voldoen aan de voorwaarden van de loyaliteitsregeling kunnen hun gewone aandelen laten omzetten in een bijzonder soort (loyaliteits)aandelen. ${ }^{17}$

De conversieregeling toont meteen een mogelijk nadeel van de soortaandelenroute aan: de te converteren aandelen moeten van de beurs worden gehaald en zijn daar dus niet meer verhandelbaar (behoudens reconversie). Deze vorm van de soortaandelenroute brengt ook nog andere uitdagingen met zich op het punt van uitgifte, toekenning, volstorting en overdraagbaarheid. Kiest een vennootschap binnen de soortaandelenroute voor aparte loyaliteitsaandelen naast de gewone beursgenoteerde aandelen, dan is een regeling nodig om ervoor te zorgen dat de aandeelhouder de loyaliteitsbonus verliest als hij niet meer voldoet aan de voorwaarden of zijn geregistreerde belang vervreemdt. ${ }^{18}$ De aandeelhouderschapsroute is hier in het voordeel: omdat het stemrecht is verbonden aan het aandeelhouderschap van een kwalificerende aandeelhouder, vervalt het als de aandeelhouder niet langer aan alle voorwaarden voldoet of zijn belang vervreemdt. De aandeelhouderschapsroute vergt dus geen complexe aanbiedings-, intrekkings- of conversieregelingen. ${ }^{19}$

Het is echter in het bijzonder het soort loyaliteitsregeling dat de keuze voor de juridische vormgeving bepaalt. Het eerste Nederlandse initiatief tot invoering van een loyaliteitsregeling kwam van DSM en betrof loyaliteitswinstrecht, gecreëerd via

15. Asser/De Serière 2-IV 2018/147; M. van Olffen, Nederlandse loyaliteitsaandelen met een Frans sausje, OR 2013/67, nr. 6-9; M. van Olffen, Loyaliteitsaandelen, WPNR 2006/6687, nr. 4-7; Kamerstukken II 2010/11,31980, 48, p. 3. Vgl. Clottens 2011, p. 333.

16. Deze route is gekozen bij CNH, FCA, Ferrari en Exor, waarover verder noot 25. Vgl. Van Olffen 2013, nr. 6-9 en 15; Van Olffen 2006, p. 780. Zie ook Asser/Van Solinge \& Nieuwe Weme 2-IIa 2013/185 en 311.

17. Zie hierover P.H.N. Quist, Conversie en aandelen (VDHI nr. 149), Deventer: Wolters Kluwer 2018, hoofdstuk 6 (in het bijzonder par. 6.3) en 11; Van Olffen 2013, nr. 8; De Jongh 2009, nr. 2; Van Olffen 2006, nr. 4; Van Olffen, Conversie van aandelen, WPNR $1997 / 6253$, p. 50 , par. 2.3 (e.v.).

18. Waarover verder Kamerstukken II 2010/11, 31980, 48, p. 4-5; Van Olffen 2013; Van Olffen 2006.

19. Vgl. ook de Ondernemingskamer in Hof Amsterdam (OK) 28 maart 2007, JOR 2007/118 (DSM), r.o. 3.12; HR 14 december 2007, JOR 2008/11 (DSM), ov. 3.4 en 3.11-3.13 van de conclusie van de A-G en r.o. 3.3 van de Hoge Raad-uitspraak. de aandeelhouderschapsroute. ${ }^{20}$ De Ondernemingskamer verklaarde deze route ongeldig, omdat artikel 2:92 lid 1 Burgerlijk Wetboek (BW) het onmogelijk zou maken aan alle aandelen van hetzelfde soort verschillende rechten en verplichtingen te verbinden; alleen door soortaandelen te creëren kan onderscheid worden gemakt tussen rechten die aan aandelen zijn verbonden. Daarom was het volgens de Ondernemingskamer niet mogelijk om, zonder soortaandelen te creëren, loyaliteitswinstrecht toe te kennen aan enkel de aandeelhouders die deelnemen aan de loyaliteitsregeling. ${ }^{21}$ Daarentegen vond de Hoge Raad de keuze van DSM om voor loyaliteitswinstrecht geen soortaandelen te creëren toelaatbaar: artikel 2:92 lid 1 jo. artikel 2:105 lid 1 en 6 BW vereisen niet dat aan onderscheiden aandelen van hetzelfde soort altijd dezelfde winstrechten zijn verbonden, noch dat voor onderscheid soortaandelen worden gecreëerd. Het enige vereiste is een statutaire basis voor die differentiatie. ${ }^{22}$

Dat lijkt mij voor winstrecht goed verdedigbaar, maar de vraag is of dit ook opgaat voor stemrecht. ${ }^{23}$ Artikel 2:118 BW legt voor de berekening van het stemrecht telkens een verband met (de nominale waarde van) de aandelen. In zoverre is de aandeelhouderschapsroute dus afgesloten en zijn soortaandelen met verschillende nominale waarde vereist. ${ }^{24}$ Artikel 2:118 lid 5 BW maakt afwijkende stemrechtregelingen mogelijk, maar begrenst die mogelijkheden (feitelijk, voor beursvennootschappen) tot maximaal zes stemmen per eenzelfde aandeelhouder. Voor zover lid 5 ruimte biedt om verschillend stemrecht aan houders van hetzelfde soort aandelen toe te kennen (de aandeelhouderschapsroute dus), maakt deze begrenzing loyaliteitsstemrecht feitelijk onmogelijk. Wellicht verklaart het voorgaande waarom de enige mij bekende Nederlandse praktijkvoorbeelden van loyaliteitsregelingen zijn geconstru-

20. Zie Persbericht DSM 27 september 2006 en verder R. Pieterse, Evenwicht van bedrijven verstoord, FD 21 februari 2006 en R. Munsters, R.H. Maatman \& G.T.M.J. Raaijmakers, Geen Amerikaanse governance-toestanden, FD 1 maart 2006, en vanuit academisch oogpunt Van Olffen 2006.

21. Hof Amsterdam (OK) 28 maart 2007, JOR 2007/118 (DSM), r.o. 3.11-3.12.

22. HR 14 december 2007, JOR 2008/11 (DSM), r.o. 3.3. Zie ook Van Olffen 2006, p. 780; ov. 3.21 en 3.26 van de conclusie bij de DSMuitspraak (ECLI:NL:PHR:2007:BB3523). Overigens stelt P.M. Storm in zijn nooit bij de OK-uitspraak in OR 2007/138 dat loyaliteitswinstrecht ook via art. 2:105 lid $1 \mathrm{BW}$ kan worden ingevoerd, omdat 'die regeling zelf naast het recht op het "gewone" dividend staat en dat daarvoor geen nieuw soort aandelen behoeft te worden geschapen'.

23. De Hoge Raad heeft het over 'art. 2:92 lid 1, gelezen in verband met het bepaalde in art. 2:105 $\mathrm{BW}$ en over 'in omvang gelijke aanspraken op dividend' (mijn cursivering).

24. Vgl. het oordeel van de Ondernemingskamer over loyaliteitswinstrecht in Hof Amsterdam (OK) 28 maart 2007, JOR 2007/118 (DSM), r.o. 3.11-3.12. Het verband tussen aandeel en stemrecht komt ook tot uitdrukking in HR 30 juni 1944, NJ 1944/465 (Wennex); Rb. Den Haag 29 september 2017, JOR 2018/36 (Magic Marble), r.o. 6.9-6.10. Vgl. ook J.M. Blanco Fernández, Rechtmatigheidsgrenzen van stemovereenkomsten, WPNR 2005/6626, p. 515. Kennelijk anders: Slagter/Assink, Compendium 2013, p. 594. Ik laat dit verder rusten. 
eerd via de (meer bewerkelijke) soortaandelenroute: deze voorbeelden betreffen allemaal loyaliteitsstemrecht. ${ }^{25}$

\subsection{Frankrijk}

De Franse wet bevat al jaren bepalingen over loyaliteitsregelingen. Voor loyaliteitsstemrecht bevat artikel L225-123 van de Code de Commerce (CdC) al sinds 1903 een regeling. ${ }^{26}$ Artikel L232-14 CdC bevat een loyaliteitswinstrechtregeling, ingevoerd in $1994 .{ }^{27}$ Beide bepalingen zijn hoofdzakelijk ingevoerd om rechtsonzekerheid over de geldigheid van loyaliteitsregelingen te voorkomen. ${ }^{28}$ Een groot deel - meer dan de helft - van de Franse beursvennootschappen heeft een loyaliteitsstemrechtregeling. ${ }^{29}$

Vóór 2014 gaf artikel L225-123 CdC vennootschappen de mogelijkheid in de statuten op te nemen dat aandeelhouders aanspraak konden maken op dubbel stemrecht als zij hun aandelen op naam zouden registreren bij de vennootschap en de aandelen vervolgens voor ten minste twee jaar zouden aanhou-

25. Aandeelhouders van FCA, CNH en Ferrari die hun aandelen registreren, kunnen na drie jaar aanspraak maken op loyaliteitsstemrecht. Ook Exor kent een soortgelijke regeling met twee soorten loyaliteitsaandelen, met wachttijden van respectievelijk vijf en tien jaar. Zie art. 4 en 19.11 van de statuten van $\mathrm{CNH}$, art. 5 en 20.11 van de statuten van zowel FCA als Ferrari, en art. 13 van de statuten van Exor. Zie A.A. Bootsma, Loyaliteitsstemrecht naar Italiaans recht en bij Fiat Chrysler Automobiles NV, OR 2015/5; Van Olffen 2013 en 2006.

26. 'One share, one vote' is echter ook daar uitgangspunt. Zie A.A Bootsma, Loyaliteitsstemrecht in het Franse wetsvoorstel-Florange, OR 2014/43; P. Merle \& A. Fauchon, Droit commercial. Sociétés commerciales, Parijs: Dalloz 2009, nr. 307; M. Storck \& T. de Ravel d'Esclapon, Faut-il supprimer les actions à droit de vote double en droit français? Bulletin Joly Sociétés 2009, afl. 1, p. 90 en 92; S. Boubaker \& F. Labégorre, Le recours aux leviers de contrôle: le cassatie des sociétés cotées françaises, Revue Finance Contrôle Stratégie 2008, afl. 3, par. 1.1 en 3.2; Valter-rapport, Travaux de la commission, II, titre III, article 5 , par. 1, sub a (directe link: www.assembleenationale.fr/14/rapports/ r1283.asp\#P1208_286841).

27. Clottens 2011, p. 70; Merle \& Fauchon 2009, nr. 295-1; M.L. Lennarts \& M.S. Koppert-van Beek, Loyalty Dividend and the EC Principle of Equal Treatment of Shareholders, ECL 2008/4, p. 176.

28. M. Cozian, A. Viandier \& F. Deboissy, Droit des sociétés, Parijs: LitecLexisNexis 2010, nr. 712; Y. Guyon, La loi du 12 juillet 1994 sur le dividende majoré, Revue des Sociétés 1995 (https://www.dalloz.fr/ documentation/Document?id=REVSOC/CHRON/1995/0001\& FromId=CODES_CCOM) par. 2 .

29. Voor de Loi Florange was het percentage $56,7 \%$; na de invoering steeg het naar 69,3\%, aldus M. Becht e.a., ECGI - Law Working Paper No. 398/2018, https://papers.ssrn.com/sol3/papers.cfm?abstract_id= 3166494, p. 21. Zie voorts het Valter-rapport, Travaux de la commission, II, titre III, article 5, par. 1, sub b (www.assembleenationale.fr/14/ rapports/r1283.asp\#P1217_289103); Storck \& De Ravel d'Esclapon 2009; N. Chene, Le droit de vote double en France, 2008, www. vernimmen.net/ftp/NChene_Memoire_DDVdoubles.pdf, p. 27 en 31-33; Boubaker \& Labégorre 2008, par. 3.1.1 (http://crego.ubourgogne.fr/images/stories/rev/113124.pdf); L. Enriques \& P. Volpin, Corporate Governance Reforms in Continental Europe, Journal of Economic Perspectives 2007, afl. 1, p. 117 en 119; J.-N. Caprasse e.a., Proportionality between ownership and control in EU listed companies. Report on the proportionality principle in the European Union, 2006, p. 44-45. Zie ook De Jongh 2009, par. 2.2, nr. 7 en 4.3, nr. 34. den. ${ }^{30}$ In 2014 veranderde de 'Loi Florange' de loyaliteitsstemrechtregeling voor beursvennootschappen van 'opt-in' naar 'opt-out'. Sindsdien is dus geen statutaire basis meer nodig voor deze loyaliteitsregeling: uitgangspunt is dat andeelhouders hun aandelen kunnen registreren, waarna zij - na twee jaar - dubbel stemrecht hebben. Wil de beursvennootschap deze regeling niet, dan moeten de statuten dit duidelijk maken. De wetgever vond het namelijk onwenselijk dat de regeling niet zou gelden als wel een meerderheid van de aandeelhouders voor invoering heeft gestemd, maar die meerderheid niet de (voor statutenwijziging en invoering van loyaliteitsstemrecht) vereiste tweederdemeerderheid bedroeg. Het artikel is van toepassing op alle vennootschappen met hoofdkantoor in Frankrijk - kortweg: SA's - ook als ze in het buitenland beursgenoteerd zijn. ${ }^{31}$

Artikel L232-14 CdC maakt een statutaire regeling mogelijk waarmee aandeelhouders aanspraak kunnen maken op tot $10 \%$ meer dividend als zij hun aandelen voor een periode van ten minste twee jaar hebben aangehouden. Voor beursvennootschappen kan elke aandeelhouder voor maximaal $0,5 \%$ van het totale kapitaal van de vennootschap gebruikmaken van de regeling. ${ }^{32}$

Interessant is dat Frankrijk de aandeelhouderschapsroute heeft gekozen: de loyaliteitsregelingen hebben niet de vorm van een aparte klasse (loyaliteits)aandelen, maar de loyaliteitsaandeelhouder ontleent het loyaliteitswinstrecht of het loyaliteitsstemrecht aan het feit dat hij, als aandeelhouder, zijn aandelen voor de registratieperiode aanhoudt. ${ }^{33}$ Zo ontwijkt de Franse regeling dus de problemen die de soortaandelenroute waar de Nederlandse praktijk (op DSM na) voor heeft gekozen - met zich brengt. ${ }^{34}$ Alleen houders van aandelen op naam kunnen aanspraak maken op loyaliteitsstemrecht. Zo kan de vennootschap daadwerkelijk verifiëren dat de aandeelhouder de aandelen conform de voorwaarden aanhoudt, en bovendien met hem in dialoog treden. ${ }^{35}$

30. J. Delvoie \& C. Clottens, Accountability and short-termism: some notes on loyalty shares, Law and Financial Markets Review 2015, afl. 1, p. 20; Clottens 2011, p. 72; Merle \& Fauchon 2009, p. 364-366, nr. 307-309.

31. C. Cardon, Franchissement de seuil par acquisition de droits de vote double et OPA obligatoire, Bulletin Joly Bourse 2015/10, p. 452; F. Peltier, L'attribution d'un dividende majoré à l'actionnaire stable, Bulletin Joly Bourse 1993/5, p. 551; Valter-rapport, Travaux de la commission, II, titre III, article 5, par. 2, sub a (directe link: www. assembleenationale.fr/14/rapports/r1283.asp\#P1208_286841).

32. Merle \& Fauchon 2009, nr. 295-1; Guyon 1995, nr. 11 en 15.

33. Dit is relevant omdat aandeelhouders moeten instemmen met een wijziging van de rechten verbonden aan hun aandelen (art. L225-99 CdC, dat doet denken aan art. 2:81/191 BW). Zie Delvoie \& Clottens 2015, p. 21; Clottens 2011, p. 353; Storck \& De Ravel d'Esclapon 2009, p. 92 (met verwijzingen naar andere opvattingen); Chene 2008, www. vernimmen.net/ftp/NChene_Memoire_DDVdoubles.pdf, p. 17; Guyon 1995, par. 14.

34. Zie voorts noot 19 .

35. Dit was een van de beweegredenen van DSM. Zie Lennarts \& Koppertvan Beek 2008, p. 173. 


\section{Maandblad \\ Ondernemingsrecht}

\subsection{Verenigde Staten}

De Verenigde Staten kennen of kenden een beperkt aantal (12) vennootschappen met loyaliteitsaandelen. ${ }^{36}$ Bekender zijn de verwante 'dual class'-structuren, waar de 'insiders' aandelen met veel stemrecht ontvangen en overige beleggers aandelen met weinig of geen stemrecht krijgen. Zo houden de insiders - vaak de oprichters - de controle over de vennootschap zonder dat zij een al te groot deel van de aandelen hoeven te houden. ${ }^{37}$

Net zoals Nederland neemt Delaware ${ }^{38}$ 'one share, one vote' ('OSOV') als uitgangspunt, maar kunnen aandeelhouders statutair anders overeenkomen. ${ }^{39}$ Evenmin als Nederland kent Delaware een concrete wettelijke grondslag voor loyaliteitsregelingen, maar is het wel mogelijk deze statutair te construeren. Dat het vennootschapsbestuur de (beleids)vrijheid heeft loyaliteitsstemrecht in te voeren, is bepaald in de Williams v. Geier-uitspraak. ${ }^{40}$

Opvallend aan de Amerikaanse loyaliteitsstemrechtregelingen is dat beleggingsinstellingen als uitgangspunt geen bonusstemrecht kregen: zij werden (als uitgangspunt, dus weerlegbaar) aangemerkt als kortetermijnaandeelhouders. Zodoende ligt de bewijslast van het zijn van langetermijnaandeelhouder bij de aandeelhouders en hoeft de vennootschap voor het controleren hiervan geen kosten te maken. Ook wilden vennootschappen certificeringsstructuren - behoudens tegenbewijs - uitsluiten: zij wilden voorkomen dat het juridisch belang in één entiteit werd ondergebracht, terwijl het economisch belang vrijelijk van hand kon wisselen. Het doel was immers aandeelhouders hechter te betrekken. ${ }^{41}$

In de Verenigde Staten zijn loyaliteitsstructuren ook wel 'high-low' ingevoerd. Dit wil zeggen dat zittende aandeelhouders direct met de invoering van de loyaliteitsregeling de loyaliteitsbonus krijgen. Deze bonus verliezen zij weer als zij hun aandelen later verkopen. De kopers moeten de aandelen dus

36. Zie Berger e.a. 2017, p. 305 e.v.

37. Voorbeelden zijn Facebook, Alphabet, Spotify en Snap. Zie Berger e.a. 2017, p. 303-305 en 319-320; J.M. de Jongh, Aanpassing MSCI-indices bij dual class shares, OR 2018/47, p. 292 en 294.

38. Regelingen omtrent aandeelhouders zijn voorbehouden aan de staten. Ik neem het recht van Delaware tot uitgangspunt, omdat de meeste Amerikaanse vennootschappen nog altijd onder die jurisdictie vallen. Zie Berger e.a. 2017, p. 298 en 316; Bootsma 2016, p. 154; W.J. Zwalve, C.Æ. Uniken Venema’s Common law \& civil law, Deventer: Kluwer 2008, p. 83-92.

39. Statuten worden in Delaware (kortweg) gezien als overeenkomst tussen vennootschap en aandeelhouders. Zie verder (genuanceerd) H. Hershkoff \& M. Kahan, Forum-selection provisions in corporate contracts, Washington Law Review 2018, p. 275-286 met verwijzingen; Berger e.a. 2017, p. 316-321; Bolton \& Samama 2013, p. 13-16.

40. Williams v. Geier, 671 A.2d 1368, 1376 (Del. 1996). Vgl. ook (iets anders dan Williams v. Geier) de IRA Frust FBO Bobbie Ahmed v. Crane-uitspraak, No. 12742-CB (Del. Ch. 2017), https://courts. delaware.gov/Opinions/Download.aspx?id=266400, p. 20-22.

41. L.L. Dallas \& J.M. Barry, Long-term shareholders and time-phased voting, Delaware Journal of Corporate Law 2016, p. 603-604. opnieuw registreren en de wachttermijn uitzitten. ${ }^{42}$ Uiteraard is het ook mogelijk loyaliteitsregelingen 'low-high' in te voeren: alle aandeelhouders moeten dan de wachttijd uitzitten.

\section{Analyse}

\subsection{De argumenten voor en tegen}

\section{Positie van de aandeelhouder: langetermijnbetrokkenheid of oligarchie?}

Het centrale argument voor loyaliteitsregelingen is dat zij kortetermijnhandelen zouden ontmoedigen en langetermijnhandelen zouden bevorderen door te faciliteren dat aandeelhouders hun aandelen langer aanhouden. Door dat signaal kan de vennootschap bovendien langetermijnaandeelhouders aantrekken en kortetermijnaandeelhouders afschrikken. ${ }^{43}$ Langetermijnbetrokkenheid kan aandeelhouders bovendien prikkelen meer actief te zijn in de vennootschap. Zo stelde Hirschman dat loyaliteitsregelingen '[are] a force which, in the act of postponing exit, strengthens voice'. Zodoende kunnen loyaliteitsregelingen leiden tot meer betrokken aandeelhouders, die zich het langetermijnsucces van de vennootschap ten doel stellen, en de positie van deze 'wenselijke' aandeelhouders versterken en van 'onwenselijke' aandeelhouders verzwakken, terwijl alle aandeelhouders in beginsel een gelijke kans hebben om deel te nemen aan de loyaliteitsregeling. ${ }^{44}$

Tegen het voorgaande is wel aangevoerd dat loyaliteitsregelingen niet interessant genoeg zijn, omdat de bonus niet voldoende omvangrijk of nuttig genoeg is. ${ }^{45}$ Loyaliteitswinstrecht zou bovendien leiden tot 'luie', passieve aandeelhouders: zij hoeven immers alleen maar hun aandelen aan te houden om aanspraak te kunnen maken op het bonusdividend. Bovendien hebben zij, vergeleken met niet-loyaliteitsaandeelhouders, minder prikkels om te engageren met de vennootschap: hun winstaanspraak is disproportioneel aan hun inbreng en zij strijken dus sowieso een groter deel van de taart op. ${ }^{46}$

Het beeld uit de praktijk is hier gemengd. Voor zover ik kon nazoeken, komt in Nederland alleen loyaliteitsstemrecht voor, en wel bij een handvol beursvennootschappen. ${ }^{47}$ Lichtende voorbeelden in Frankrijk zijn Credit Agricole, L'Oréal en Air Liquide. Van het aandelenkapitaal in deze laatste was 35\% geregistreerd voor loyaliteitswinstrecht en ontving 30\% al loyaliteitsdividenden. Verder is de Franse loyaliteitswinstrechtre-

42. Berger e.a. 2017 , p. 305, 307, 317 en 320; Dallas \& Barry 2016, p. 549-551 en 576-592; De Jongh 2009, par. 19.

43. Berger e.a. 2017, p. 308-309; Dallas \& Barry 2016, p. 571; Bolton \& Samama 2013, p. 22-26.

44. A.O. Hirschman, Exit, Voice, and Loyalty, Cambridge, MA: Harvard University Press 1970 , p. 92 . Zie ook Berger e.a. 2017, p. 308-309 en 319-320; Generation Foundation, Building a Long-term Shareholder Base. Assessing the potential of loyalty-driven securities, 2013, p. 9-10: Bolton \& Samama 2013, p. 21-22; De Jongh 2009, par. 3.3.

45. Zie De Jongh 2009, par. 4.3 en de literatuur in noot 13.

46. Berger e.a. 2017, p. 310; Generation Foundation 2013, p. 12; M.C. Schouten, Loyaal aan het eigen belang, OR 2011/122.

47. Zie noot 25 
geling echter weinig ingevoerd. ${ }^{48}$ De beperking van de regeling tot $0,5 \%$ van het totale kapitaal van de vennootschap maakt haar namelijk weinig spannend en daarom weinig populair. ${ }^{49}$ Loyaliteitsstemrechtregelingen zijn daarentegen wél erg populair in Frankrijk (ook al voor de Loi Florange): deze zijn aanwezig in bijna $90 \%$ van de Franse familiegecontroleerde beursvennootschappen en meer dan de helft van de beursvennootschappen met een divers aandeelhoudersbestand. ${ }^{50}$ In de Verenigde Staten daarentegen bleken institutionele beleggers van het type langetermijnbelegger niet meer geneigd te investeren in vennootschappen met loyaliteitsstemrechtregelingen. ${ }^{51}$ Invoering van loyaliteitsstemrecht bleek bovendien niet te leiden tot meer langetermijnaandeelhouderschap. Dit zou echter kunnen samenhangen met de onbekendheid van de figuur. ${ }^{52}$ De Franse situatie geeft enige steun aan dat vermoeden: de daar meest populaire regeling - inzake loyaliteitsstemrecht - bestaat al ruim een eeuw en zit dus ook al decennialang in de gereedschapskist van de juridische en ondernemingspraktijk. De loyaliteitswinstrechtregeling geniet minder populariteit, maar bestaat ook veel minder lang. Kortweg lijkt de (voorzichtige) conclusie op dit punt dat loyaliteitsregelingen wel degelijk interessant kunnen zijn en kunnen bijdragen aan langetermijnaandeelhouderschap, mits goed geïmplementeerd en voldoende interessant gemaakt.

Tegelijkertijd wijzen critici op het reële risico dat loyaliteitsregelingen - vooral loyaliteitsstemrecht - protectionistisch of als beschermingsconstructie uitpakken en oligarchievorming in de hand werken. ${ }^{53}$ Juist oprichters(families) en andere grootaandeelhouders profiteren immers van de loyaliteitsregeling, omdat zij niet snel zullen uitstappen. Bovendien kunnen deze aandeelhouders zodoende met minder aandelen toch een controlerend belang houden. Dit kan zelfs voor hen een voorwaarde zijn om de vennootschap naar de beurs te brengen. Een aantal Nederlandse beursvennootschappen is hiervan

48. Delvoie \& Clottens 2015, p. 20; Bolton \& Samama 2013, p. 11-12; Guyon 1995, nr. 17-19.

49. De Beurs 2011, p. 16 en 18; Guyon 1995, par. 14.

50. Zie voor de percentages Becht e.a. 2018, p. 21; het Valter-rapport, Travaux de la commission, II, titre III, article 5, par. 1 , sub b (www. assembleenationale.fr/14/rapports/r1283.asp\#P1217_289103);

E. Ginglinger \& J. Hamon, Ownership, control and market liquidity, Revue Finance 2012, afl. 2, par. 2.2; De Jongh 2009, par. 2.2; Chene 2008, p. 27 en 31-33; Boubaker \& Labégorre 2008, par. 3.3; Caprasse e.a. 2006 , p. ; $44-45$

51. Dallas \& Barry 2016, p. 623-630. Het omgekeerde gold overigens evenmin: institutionele beleggers met een kortetermijnfocus waren niet minder geneigd te beleggen in vennootschappen met loyaliteitsstemrechtregelingen.

52. Aldus Dallas \& Barry 2016, p. 593, 623 en 629-630 met nuanceringen bij de robuustheid van hun analyse, waaronder de kleine sample size.

53. Social classes. Non-voting shares, Economist 30 september 2017, p. 62-63; French companies do not need the 'Loi Florange', FT 8 april 2015. Zie voorts Bootsma \& Keijzer 2017; Nota modernisering ondernemingsrecht, Kamerstukken II 2016/17, 29752, 9, p. 14 en 20; Dallas \& Barry 2016, p. 547-548 en 551; L. Strine, The Soviet constitution problem in comparative corporate law. Testing the proposition that European corporate law is more stockholder focused than U.S. corporate law, Southern California Law Review 2016, p. 1248 en 1283-1284; Delvoie \& Clottens 2015, p. 21 en 24; De Jongh 2009, vooral par. 2.2 en 10; Chene 2008, p. 18 beticht, ${ }^{54}$ maar ook in Frankrijk lijkt dit een reëel risico. De precieze percentages hangen af van de selectiecriteria, maar duidelijk is dat veel Franse beursvennootschappen - meer dan de helft - een loyaliteitsstemrechtregeling hebben en een groot deel ook een grootaandeelhouder heeft. Grootaandeelhouders lijken het loyaliteitsstemrecht inderdaad vooral aan te wenden om ervoor te zorgen dat zij een meerderheid bezitten. ${ }^{55}$ Dit beeld wordt echter genuanceerd door het feit dat van de vennootschappen met een divers aandeelhoudersbestand nog steeds meer dan de helft een loyaliteitsstemrechtregeling heeft. ${ }^{56}$ Bovendien valt de 'kloof tussen financieel belang en stemrecht in Frankrijk - pakweg 10 procentpunten - mee. ${ }^{57}$ Ook in de Verenigde Staten hadden vennootschappen met loyaliteitsregelingen over het algemeen een geconcentreerd aandeelhoudersbestand. ${ }^{58}$ Wel was de kloof tussen financieel belang en stemrecht in de Verenigde Staten een stuk groter dan in Frankrijk: gemiddeld 47 procentpunten. ${ }^{59}$ Daarbij komt nog dat Amerikaanse vennootschappen bepaalde beleggers uitsloten van loyaliteitsstemrecht.

Dit 'oligarchieprobleem' is een risico dat zowel wetgever als vennootschap goed in het oog moet houden. Als de loyaliteitsregeling in beginsel en redelijkerwijs openstaat voor elke aandeelhouder, kan dit het risico op oligarchievorming althans verminderen. In dat opzicht zijn loyaliteitsregelingen een vooruitgang op dual class share-structuren en kunnen ze zelfs een gulden middenweg vormen tussen vennootschappen met dergelijke structuren en de OSOV-vennootschappen. ${ }^{60} \mathrm{Die}$ structuren kennen immers ook nadelen. De OSOV-vennootschappen zijn kwetsbaar voor kortetermijnaandeelhouders, aangezien die simpelweg kunnen instappen zonder dat op langetermijnwaardecreatie gerichte aandeelhouders daar een sterk tegengewicht voor kunnen bieden. Tegelijkertijd slaan dual class share-vennootschappen weer te ver door naar de andere (oligarchische) kant. Het structureel ontnemen van het stemrecht aan alle aandeelhouders behalve (vaak) de oprichter(s) is voor veel beleggers vanzelfsprekend bezwaarlijk. Loyaliteitsregelingen geven daarentegen elke aandeelhouder een gelijke

54. Zie nader voor de Nederlandse situatie R. Abma e.a., De algemene vergadering van Nederlandse beursvennootschappen (R\&P ONR9), Deventer: Wolters Kluwer 2017, p. 116 (met verwijzingen); Buirma 2016; Bootsma 2016, o.a. par. 4.2 en 3.1.

55. Concreet: gemiddeld gaf een financieel belang van $45,15 \%$ recht op een stemrecht van $54,81 \%$. Bij familiegecontroleerde vennootschappen lag de kloof overigens maar marginaal hoger, net boven de 10\%. Zie Chene 2008, p. 37-38.

56. Zie noot 50 .

57. Zie noot 55 .

58. Dallas \& Barry 2016, p. 620-622

59. Dallas \& Barry 2016, p. 635-637, P.A. Quimby, Addressing corporate short-termism through loyalty shares, Florida State University Law Review 2013, p. 406.

60. Zie over dual share-structuren noot 37 en de hoofdtekst daarbij. 


\section{Maandblad}

Ondernemingsrecht

kans, ${ }^{61}$ zeker door de bonus bij invoering van de loyaliteitsregeling direct aan alle aandeelhouders toe te kennen (high-low) of juist te onthouden (low-high). ${ }^{62} \mathrm{Wel}$ moet worden onderkend dat het risico bestaat dat loyaliteitsregelingen de facto vooral ten goede komen aan grootaandeelhouders, ten koste van de positie van minderheidsaandeelhouders. High-low- of low-high-invoering kan weer bijdragen aan het verminderen van dit risico.

$\mathrm{Nu}$ is ook de aanwezigheid van een grootaandeelhouder - net zoals een zelfstandiger bestuur, waarover hierna - niet per se een slechte zaak. Dergelijke aandeelhouders kunnen relatief veel invloed uitoefenen en tegelijkertijd daar met de minderheidsaandeelhouders de vruchten van plukken. Dit hoeft niet te betekenen dat zij dusdanig dominant worden dat van echte oligarchie of zelfverrijking gesproken kan worden. ${ }^{63}$ Kortom, vennootschappen met loyaliteitsregelingen kunnen de voordelen van een divers aandeelhoudersbestand combineren met de voordelen van het hebben van een controlerende aandeelhouder en de nadelen van beide systemen mitigeren.

Zijdelings gerelateerd is het bezwaar dat loyaliteitsregelingen zouden kunnen leiden tot liquiditeitsproblemen. Aandeelhouders die deelnemen aan een loyaliteitsregeling hebben immers een prikkel om hun aandelen aan te houden. Als een significant deel van de aandeelhouders deelneemt aan de loyaliteitsregeling, kan het volume van de handel in die aandelen afnemen, met alle gevolgen voor de prijs van dien. Dit probleem wordt gematigd door een positief gevolg van loyaliteitsregelingen, namelijk dat loyaliteitsaandeelhouders (kortweg) voor dezelfde hoeveelheid stem- of winstrechten minder aandelen nodig hebben. ${ }^{64}$ Deze aandeelhouders kunnen daardoor diversifiëren en dus een deel van hun belang verkopen. Dit komt de liquiditeit van het aandeel weer ten goede. Bovendien bleek dat althans de Franse loyaliteitsstemrechtregeling geen invloed had op de liquiditeit van aandelen van grote bedrijven en zelfs een positieve invloed op de liquiditeit van de aandelen van kleine bedrijven. ${ }^{65}$ Tegelijkertijd betekenen kleinere belangen

61. Zie over kansengelijkheid ov. 3.51 van de conclusie bij de DSMuitspraak (voor Nederland); Berger e.a. 2017, p. 305-307, 317, 320 en 322; Dallas \& Barry 2016, p. 600-601 (voor de VS). In tegenstelling tot bij bijv. Altice, Yandex en Cnova kunnen in beginsel alle aandeelhouders van CNH, FCA, Ferrari en EXOR aanspraak maken op extra stemrecht. Altice is een bijzonder geval: deze vennootschap kent een klasse aandelen met meer stemrechten die op de beurs verhandelbaar zijn, maar die ooit ter gelegenheid van een fusie zijn uitgegeven en waarop niet krachtens een loyaliteitsregeling aanspraak gemaakt kan (of hoeft te) worden.

62. Waarover voetnoot 42 .

63. De Jongh 2009, nr. 19. Overigens faciliteert het ook een soort (positieve) free riding: de niet-loyaliteitsaandeelhouders kunnen het sturen van de vennootschap als het ware uitbesteden aan de loyaliteitsaandeelhouders en de bestuurders. Zie Dallas \& Barry 2016, p. 575-576.

64. Berger e.a. 2017, p. 309-310; Dallas \& Barry 2016, p. 548-551, 619-621 en 640-642; Bolton \& Samama 2013, p. 27; De Beurs 2011, p. 15; J.M. de Jongh, Redelijkheid en billijkheid en het evenredigheidsbeginsel, in het bijzonder in de verhouding van aandeelhouders tot het bestuur, OR 2011/124, par. 2.2.2; De Jongh 2010 en De Jongh 2009, nr. 20-22 met relevante verwijzingen.

65. Ginglinger \& Hamon 2012, par. 4. voor langetermijnaandeelhouders ook dat vennootschappen een meer divers aandeelhoudersbestand hebben. Dit komt de liquiditeit ook weer ten goede.

\section{Positie van het bestuur: entrenchment}

Een ander probleem is dat in het bijzonder stemrechtregelingen bestuurders kunnen afschermen van markttucht. Beleggers die kritisch zijn op de bestuursstrategie en instappen om verbetering af te dwingen, hebben immers aanvankelijk geen loyaliteitsstemrecht en dus relatief weinig invloed. Bovendien kunnen de loyaliteitsaandeelhouders de bestuurders de hand boven het hoofd houden. Kritische beleggers kunnen dus minder makkelijk verbetering afdwingen en hun investering minder goed beschermen. Hierdoor stijgen het risico en de controlekosten voor beleggers. ${ }^{66}$ De vennootschap kan daardoor een lagere waardering hebben dan zij anders zou hebben. ${ }^{67}$

Hoewel dit zeker een aandachtspunt is, zijn verschillende nuanceringen mogelijk. Een opportunistische belegger die daadwerkelijk ruimte ziet voor structurele verbeteringen kan immers alsnog instappen en de andere (lange- en kortetermijn)aandeelhouders proberen te overtuigen van zijn visie. ${ }^{68}$ Als een dergelijke belegger bovendien daadwerkelijk een langetermijnvisie heeft, benadeelt de loyaliteitswachttermijn hem ook niet significant. ${ }^{69}$ Hij hoeft immers alleen zijn belang te registreren en vervolgens aan te houden, hetgeen een echte langetermijnbelegger toch zou doen. Daarnaast hebben ook de controlerende (loyaliteits)aandeelhouders alle reden om hun stemrechten te gebruiken om het bestuur ter verantwoording te roepen en te controleren. ${ }^{70}$ De loyaliteitsbonus compenseert bovendien de kosten die met het langetermijnaandeelhouderschap samenhangen, zoals controlekosten en kosten verbonden aan koersdalingen (of eventueel verminderde liquiditeit). ${ }^{71}$ Overigens kunnen loyaliteitsregelingen ook goed zijn voor de waardering. Langetermijnaandeelhouders en de vennootschap zullen eerder dezelfde doelen hebben, waardoor zij bij overnamepogingen samen een front kunnen vormen en een hogere koerspremie kunnen bedingen. ${ }^{72}$

Overigens is afzondering van bestuurders van de markt niet per se negatief, zoals hierboven al gezegd. Zo kan het een stabi-

66. Dallas \& Barry 2016, p. 565-566; De Jongh 2009, nr. 30; Chene 2008, p. 18-19.

67. Zie over de waarde van controle nader H.G. Manne, Mergers and the market for corporate control, Journal of Political Economy 1965, p. 110.

68. Berger e.a. 2017, p. 310; Dallas \& Barry 2016, p. 569-571.

69. Dit overigens in tegenstelling tot bij dual share-structuren, die in de regel alleen ten goede komen aan de oprichters/grootaandeelhouders. Zie voorts De Jongh 2018, p. 294; Dallas \& Barry 2016, p. 547 en 556-568; Chene 2008, p. 40.

70. Dallas \& Barry 2016, p. 572; De Jongh 2009, par. 3.2 .

71. Generation Foundation 2013, p. 9 en 13; Bolton \& Samama 2013, p. 17.

72. P.N. Wakkie en B.J. de Jong, 'Discussieverslag', in: G. van Solinge, Nederland, het Delaware van Europa? (VDHI nr. 135), 2016 p. 235-236) duidden dit aan met de term 'Dutch Premium'. Zie voorts Dallas \& Barry 2016, p. 569 en 605-606. Zie voor kanttekeningen De Jongh 2009, par. 4.1. 
liserende factor zijn: omdat de bestuurders minder gevoelig zijn voor opportunistische of speculerende activistische beleggers als hedgefondsen, kunnen zij vrijer investeren en ver(der) vooruitkijken. ${ }^{73}$ Het bewijs hiervoor is echter gemengd. Belot vond dat Franse familievennootschappen die een loyaliteitsstemrechtregeling met een lange wachttermijn hebben, systematisch minder goed presteren. ${ }^{74}$ Dallas en Barry constateerden voor de Verenigde Staten dat vennootschappen met loyaliteitsstemrechtregelingen wél beter presteerden dan de markt, maar dat dit ook zo was vóór de invoering van de loyaliteitsstemrechtregeling. Hoewel wellicht niet direct een argument voor loyaliteitsstemrecht, is het wel een indicatie dat het soort bedrijf(svoering) dat loyaliteitsregelingen produceert, samenhangt met goede bedrijfsprestaties. Een aandeel DSM is nu bijvoorbeeld pakweg tweemaal zoveel waard als ten tijde van de aankondiging van het loyaliteitsplan. ${ }^{75}$

\section{Gelijkheid van aandeelhouders}

Een veelgehoord punt van kritiek is dat loyaliteitsregelingen het OSOV-beginsel dan wel het gelijkheidsbeginsel schenden. ${ }^{76}$ Daar lijkt mij niet noodzakelijkerwijs sprake van.

Allereerst is het in veel landen, waaronder Frankrijk en de Verenigde Staten, mogelijk af te wijken van het OSOV-beginsel. Ook in Nederland is afwijking van het OSOV-beginsel bijvoorbeeld mogelijk via artikel 2:118 lid 4 en 5 en 2:92 lid 1 BW ('Voor zover bij de statuten niet anders is bepaald (...)'). ${ }^{77}$ De DSM-uitspraak van de Hoge Raad bevestigde dat een loyaliteitsregeling ook een rechtsgeldige afwijking kan zijn. ${ }^{78}$

Ook het gelijkheidsbeginsel (art. 2:92/201 lid 2 BW) hoeft geen obstakel te vormen. Dit vergt dat aandeelhouders in gelij$k e$ situaties gelijk worden behandeld. Gewone en loyaliteitsaandeelhouders bevinden zich wat betreft hun inbreng inderdaad in gelijke situaties, maar niet noodzakelijkerwijs wat betreft hun betrokkenheid. ${ }^{79}$ Wordt het gelijkheidsbeginsel niet evengoed geschonden als een aandeelhouder die pas net is ingestapt hetzelfde stemrecht heeft als een aandeelhouder die al jaren 'door dik en dun' betrokken is bij de vennootschap?

73. Berger e.a. 2017, p. 308-309; Dallas \& Barry 2016, p. 547-548, 561-564, 568-570 en 604-605; Quimby 2013, p. 397-400; Clottens 2011, p. 73; De Jongh 2009, nr. 14-16 en 19; Chene 2008, p. 20.

74. F. Belot, Droits de vote double et 'voting-caps': quel impact pour les entreprises françaises? (Mémoire de DEA), Parijs 2005.

75. Dallas \& Barry 2016, p. 552; Clottens 2011, p. 333, bij voetnoot 1559; De Jongh 2009, par. 4.3 en 4.4; DSM-jaarverslag 2006, p. 82 en DSMjaarverslag 2007, p. 82.

76. Nederland kent het OSOV-beginsel in art. 2:92/201 lid 1 en $2: 118 / 228$ lid 2 en 3 BW. Het gelijkheidsbeginsel is in Nederland opgenomen in art. 2:92/201 lid 2 BW. Dit wordt gewaarborgd door art. 4 van Richtlijn 2007/36/EG (de Richtlijn aandeelhoudersrechten) respectievelijk art. 85 van Richtlijn (EU) 2017/1132 (de Richtlijn vennootschapsrecht). Zie Dallas \& Barry 2016, p. 611-612; De Jongh 2014, p. 521-524; Quimby 2013, p. 408-409; De Jongh 2009, par. 4.2; Merle \& Fauchon 2009, p. 366; Guyon 1995, nr. 2.

77. Zie Berger e.a. 2017, p. 311 en 318-320; De Jongh 2009, par. 4.2.

78. Zie noot 22

79. Zie ook Lennarts \& Koppert-van Beek 2008, p. 176; Guyon 1995 nr. 2. Anders: Clottens 2011, p. 452-453
Wanneer gevallen (on)gelijk zijn, is niet duidelijk, maar mijns inziens kan het verschil in soort aandeelhouderschap (lange versus korte termijn) in principe voldoende zijn om te kunnen spreken van 'ongelijke situaties', die dus ook ongelijk mogen worden behandeld. ${ }^{80}$ De langetermijnaandeelhouder die zich committeert zijn belang duurzaam aan te houden, zou dus een beloning/compensatie voor die toezegging mogen ontvangen. ${ }^{81}$

Uit EU-recht blijkt voorts dat ongelijke behandeling van aandeelhouders ook kan worden gerechtvaardigd als de regeling een objectief gerechtvaardigd doel heeft, geschikt en noodzakelijk is om dat doel te bereiken, en proportioneel is aan dat doel. Deze vereisten moeten per geval worden nagelopen, maar $\mathrm{ik}$ neem aan dat loyaliteitsregelingen in beginsel daaraan kunnen voldoen. ${ }^{82}$ Het Valter-rapport concludeerde ook dat de nieuwe loyaliteitsstemrechtregeling in de Loi Florange geen discriminatoir effect heeft, omdat zij Franse investeerders niet bevoordeelt, en overigens voldoet aan de twee voorwaarden voor beperking van een verkeersvrijheid (in casu de vrijheid van kapitaalverkeer): de doelen van de maatregel zijn dwingende redenen van algemeen belang en de maatregel is noodzakelijk en evenredig aan het beoogde doel. Elke aandeelhouder kan immers in beginsel deelnemen aan de loyaliteitsregeling. In zoverre heeft elke aandeelhouder dus gelijke rechten(/kansen). ${ }^{83}$ De regeling is bovendien alleen van toepassing op beursgenoteerde vennootschappen en aandelen op naam. De Franse Raad van State vond de regeling daarom 'redelijkerwijs toelaatbaar'. ${ }^{84}$

\section{Onbedoelde gevolgen}

Ten slotte kunnen loyaliteitsregelingen verschillende onbedoelde gevolgen hebben. Zo is denkbaar dat de regeling aanleiding geeft tot meld- en biedplichten. ${ }^{85}$ Daarnaast kan de regeling worden misbruikt. ${ }^{86}$ De vraag of de begunstigde van een loyaliteitsregeling ook daadwerkelijk economisch én juridisch gerechtigd is tot de aandelen, brengt kosten met zich

80. In de woorden van Guyon 1995, nr. 2: 'Quant au principe d'égalité, il n'oblige à traiter de manière identique que des personnes en situation semblable. Il ne fait pas obstacle, comme le rappelle constamment le Conseil constitutionnel, à ce que des situations différents fassent l'objet de solutions différents.'

81. De Jongh 2009, par. 20-22.

82. Aldus ook HR 31 december 1993, NJ 1994/436 (Verenigde Bootlieden); ov. 3.51-3.62 van de conclusie bij de DSM-uitspraak (ECLI:NL:PHR:2007:BB3523); A.A. Bootsma, Financiële prikkels voor aandeelhouders: tot waar mag het gelijkheidsbeginsel worden gebogen?, Den Haag: Boom 2011, par. 5.4; De Beurs 2011, par. 3 en 4; De Jongh 2009, par. 5; Lennarts \& Koppert-van Beek 2008 (met verwijzingen); J.H. Gerards, Rechterlijke toetsing aan het gelijkheidsbeginsel, Den Haag: Sdu 2002, p. 237; Guyon 1995, nr. 2.

83. Zie verder noot 61 .

84. 'Peut (...) raisonnablement être admise.' Valter-rapport, Travaux de la commission, II, titre III, article 5, par. 2, sub b (www.assemblee nationale.fr/14/rapports/r1283.asp\#P1231_292490); Lennarts \& Koppert-van Beek 2008, p. 176-177.

85. Clottens 2011, p. 353; De Jongh 2009, par. 2.1; Kamerstukken II 2010/11, 31980, 48, p. 7.

86. Bolton \& Samama 2013, p. 30-31; Lennarts \& Koppert-van Beek 2008, p. 177. 


\section{Maandblad \\ Ondernemingsrecht}

voor zowel vennootschap als aandeelhouder. Het bestuur kan hier als arbiter fungeren, maar ook technische oplossingen zijn denkbaar om (loyaliteits)aandeelhouders te identificeren, zoals via bestaande financiëlemarkteninfrastructuur of door blockchaintechnologie te benutten. ${ }^{87}$

\subsection{Een Nederlandse loyaliteitsregeling?}

Hoewel een aantal bezwaren hout snijdt, blijven er volgens mij ruim voldoende argumenten over die pleiten voor loyaliteitsregelingen. De bezwaren maken op hun beurt weer duidelijk dat een wettelijke regeling meerwaarde heeft. $\mathrm{Zij}$ kan duidelijkheid scheppen, ingewikkelde (en dus dure) constructies onnodig maken, uitwassen en misbruik voorkomen, de juiste randvoorwaarden creëren voor een effectieve regeling, en zodoende het gebruik van loyaliteitsregelingen aanzwengelen.

Omdat nog onduidelijk is of loyaliteitsstemrecht kan worden toegekend aan de aandeelhouder als zodanig, en de soortaandelenregelingen hoogst complex zijn (zie par. 3.1), lijkt het mij dan ook raadzaam een aparte regeling in te voeren die het mogelijk maakt (loyaliteits)stemrecht te verbinden aan aandeelhouderschap. Een alternatief is de route van de soortaandelen te stroomlijnen, bijvoorbeeld door volstorting, conversie of overdracht van loyaliteits(stemrecht)aandelen te regelen. Mijn voorkeur zou uitgaan naar de meer eenvoudige eerste mogelijkheid.

De Franse ervaring laat zien dat invoering van loyaliteitsregelingen niet opt-out maar opt-in - dus slechts als de aandeelhouders actief voor invoering kiezen - zou moeten zijn. Maatwerk is gepast, waarbij de vennootschap in dialoog met aandeelhouders, stakeholders en stemadviseurs kiest voor invoering. ${ }^{88}$

Een tweede belangrijk aandachtspunt is het gelijkheidsbeginsel (art. 2:92 lid 2 BW; waarover par. 4.1, subparagraaf 'Gelijkheid van aandeelhouders'): aandeelhouders in gelijke omstandigheden moeten gelijk worden behandeld. Doet een loyaliteitsregeling dat niet, dan kan deze ongelijkheid gerechtvaardigd worden als de regeling een objectief gerechtvaardigd doel heeft, geschikt en noodzakelijk is om dat doel te bereiken, en proportioneel is aan dat doel. Een eventuele wettelijke regeling moet hiermee rekening houden. ${ }^{89}$ Zo kan de wet invoering van een loyaliteitsregeling koppelen aan een bepaald doel. Een dergelijk wetsartikel zou bijvoorbeeld kunnen bepalen dat een statutaire loyaliteitsregeling dient 'ter bevordering van de lan-

87. Zie over het bestuur als spil: De Jongh 2009, par. 4.4; Lennarts \& Koppert-van Beek 2008, p. 177. Over de Wge (en buitenlandse equivalenten): De Beurs 2011, p. 16-17 en 21; Generation Foundation 2013, p. 13; Bolton \& Samama 2013, p. 30-31. Over blockchain: Berger e.a. 2017 , p. 312-316. Mits goed geïntegreerd, zullen die kosten ook meevallen; vgl. Dallas \& Barry 2016, p. 614-615.

88. De wetgever ziet evenmin heil in de Franse aanpak. Zie Kamerstukken II 2018/19, 29752, 12, p. 10; M. Stothard, French companies fight back against Florange double-vote law, FT 16 april 2015; Bootsma 2014, par. 4, met verwijzingen; Kamerstukken II 2010/11, 31980, 48, p. 4.

89. Zie noot 82 getermijnbetrokkenheid van de aandeelhouders bij de vennootschap'. In gevallen waarin de loyaliteitsregeling apert een beschermingsconstructie inhoudt, kan een dergelijke norm aanknopingspunten geven voor de rechter, bijvoorbeeld in een enquêteprocedure. Het bestaan van een regeling gekoppeld aan een concreet doel kan bovendien een bepaald vermoeden van geschiktheid, noodzakelijkheid en proportionaliteit creëren. Voorts zou de vennootschap tegemoet kunnen komen aan het proportionaliteitsvereiste door ervoor te zorgen dat de loyaliteitsregeling redelijkerwijs openstaat voor alle aandeelhouders. Daarbij is het raadzaam al bij invoering van de loyaliteitsregeling alle aandeelhouders gelijk te behandelen (door 'high-low'- of 'low-high'-invoering). Zo kan bovendien oligarchievorming worden voorkomen. Zittende aandeelhouders worden dan gelijk behandeld en nieuwe aandeelhouders - voor wie de loyaliteitsregeling ook openstaat - weten waar zij aan toe zijn. ${ }^{90} \mathrm{Bij}$ de geschiktheidsvraag is een bijzonder aandachtspunt of loyaliteitsstemrecht, -winstrecht of een combinatie het beste is voor de gegeven vennootschap.

Voorts noem ik nog een aantal losse punten waar de wetgever aan moet denken. Het kan bijvoorbeeld wenselijk zijn dat de regeling nadere uitwerking kan krijgen in een (openbaar) reglement, dat gemakkelijker kan worden gewijzigd. ${ }^{91}$ De wijzigingsbevoegdheid moet liggen bij het bestuur, maar de algemene vergadering zou een rol kunnen krijgen (onverminderd art. 2:81 BW). ${ }^{92}$ Daarnaast zouden minima, maar vooral ook maxima aan de omvang van de loyaliteitsbonus wenselijk kunnen zijn. Er is bijvoorbeeld relatief weinig interesse in de Franse loyaliteitswinstrechtregeling door haar beperkte mogelijke omvang, terwijl maxima liquiditeitsproblemen en benadeling van kleinere niet-loyaliteitsaandeelhouders kunnen tegengaan. Bovendien lijkt mij dat loyaliteitsbonussen niet binair hoeven te zijn; de bonus kan ook meerdere trappen kennen. ${ }^{93}$ Een maximale wachttermijn kan bovendien raadzaam zijn omdat een loyaliteitsregeling met een exorbitant lange wachttermijn de facto een oligarchische structuur kan zijn. ${ }^{94}$ Een gerelateerd, lastiger beslispunt is of het mogelijk moet zijn voor vennootschappen om bepaalde soorten aandeelhouders, zoals hedgefondsen, maar ook bestuurders, op voorhand uit te sluiten. Dergelijke regelingen zijn niet ondenkbaar, maar lastig af te bakenen, vooral voor hedgefondsen. Ik zou het aan vennootschappen willen laten om te bepalen welke (groepen) aandeelhouders zij van de regeling uitsluiten, maar het lijkt mij wenselijk dergelijke regelingen althans aanvankelijk beperkt te

90. Zie de noten 42 (over 'high-low'/'low-high'-invoeringen) en 61 (over gelijkheid).

91. Zie conclusie A-G Timmerman bij de DSM-uitspraak (ECLI:NL:PHR:2007:BB3523), ov. 3.32.

92. Berger e.a. 2017, p. 311-312; Lennarts \& Koppert-van Beek 2008, p. 177. Zie over art. 2:81 BW o.a. De Beurs 2011, par. 5, met verwijzingen.

93. Zoals bij Exor. Zie noot 25. Berger e.a. 2017, p. 317 noemen dit 'scaled voting', 'a voting arrangement under which the number of votes per share would decline if a shareholder owned a large enough number of shares'.

94. Kamerstukken II 2010/11, 31980, 48, p. 4-7. Zie ook de laatste alinea van de subparagraaf'Positie van het bestuur: entrenchment' hierboven. 


\section{Maandblad}

houden, mede gelet op artikel 2:92 lid 2 BW. ${ }^{95}$ De wetgever moet voorts kiezen welk middel (naast uitsluiting van gecertificeerde aandelen ${ }^{96}$ ) het meest gepast is om op een kostenefficiënte manier (loyaliteits)aandeelhouders te identificeren en misbruik van de regeling tegen te gaan. Dit kan aan het bestuur worden overgelaten - een ietwat botte bijl - of via de Wet giraal effectenverkeer (Wge) of door toepassing van blockchaintechnologie geregeld worden. ${ }^{97}$ Voorts moet de wetgever aandacht hebben voor de mogelijkheid dat loyaliteitsstemrechtregelingen leiden tot meld- of biedplichten. Een optie is loyaliteitsstemrechtregelingen te maximeren bij de biedingsdrempel. ${ }^{98}$ Verder ligt nog voor de hand de loyaliteitsbonus pro rata te laten vervallen als de aandeelhouder aandelen vervreemdt.

Ten slotte kom ik terug op de aanleiding van deze verkenning van loyaliteitsregelingen: de Richtlijn langetermijnbetrokkenheid aandeelhouders. Als de wetgever inderdaad wil dat de aandeelhouders waartoe de richtlijn zich richt - institutionele beleggers en vermogensbeheerders - zich actief op langetermijnwaardecreatie gaan richten, dan is het raadzaam een eventuele wettelijke loyaliteitsregeling - in overleg met die partijen, maar ook bijvoorbeeld de Vereniging van Effecten Uitgevende Instellingen (VEUO) - zo vorm te geven, dat zij aantrekkelijk wordt voor zowel uitgevende instellingen als aandeelhouders. Juist die partijen kunnen immers verandering afdwingen. ${ }^{99}$

\section{Conclusie}

Ik heb in dit artikel onderzocht of Nederland een regeling zou moeten invoeren die loyaliteitsstem- en loyaliteitswinstrechtregelingen faciliteert. Ik concludeer dat een dergelijke regeling meerwaarde kan hebben, als de wetgever met een aantal aandachtspunten rekening houdt. Zo zou invoering van een dergelijke regeling - in tegenstelling tot in Frankrijk - facultatief moeten zijn. Ten tweede moet de regeling een legitiem doel hebben en geschikt, noodzakelijk en proportioneel zijn. Bovendien dient de regeling enkel grenzen te stellen en vennootschappen verder zo veel mogelijk vrij te laten in de vormgeving. Bij die grenzen moet onder andere aandacht zijn voor eventuele minima en maxima van de loyaliteitsbonus, de wachttermijn, de invoering en wijziging van de loyaliteitsregeling, de voorwaarden waaronder en wijze waarop de aanspraak op de loyaliteitsregeling vervalt, de toegang ertoe, en controle op de naleving van de voorwaarden voor aanspraak op de bonus. Bovenal moet de wetgever echter breed draagvlak creëren door zowel aandeelhouders als uitgevende instellingen bij het wetgevingsproces te betrekken.
Het tot dusver beschikbare bewijs voor loyaliteitsregelingen is niet noodzakelijkerwijs overtuigend. De vermeende impopulariteit of ineffectiviteit hoeft ons echter niet tegen te houden, mits de juiste lessen worden getrokken uit buitenlandse ervaringen - hetgeen ik heb geprobeerd te doen. En, in de woorden van Martin Wolf: 'the burden of proof should not be on those who favour change'. ${ }^{100}$ Loyaliteitsregelingen zijn een begin om aandeelhouders en langetermijnwaardecreatie op één lijn te krijgen. En zodoende wellicht een bescheiden eerste stap op de weg om de aandeelhouder een meer volwaardige rol in de vennootschap toe te kennen, neen: toe te vertrouwen.

95. Zie ook De Jongh 2009; Dallas \& Barry 2016, p. 566 en 572.

96. Zie noot 41 .

97. Zie nader noot 87 en vgl. art. 3 bis van Richtlijn 2017/828.

98. Alternatief is een uitzondering op de biedplicht op te nemen, maar dat lijkt onwenselijk. In gelijke zin: French companies do not need the 'Loi Florange', FT 8 april 2015.

99. Schouten 2012, p. 209-214, al genoemd in de inleiding. 